\title{
ARTE EDUCAÇÃO: NECESSIDADE OU SUPERFLUIDADE?
}

\author{
Adriana Rosely Magro ${ }^{1}$ \\ ${ }^{1}$ Mestre em Educação, professora de Arte e Educação, doutoranda em Educação pela Universidade Federal do Espírito \\ Santo.drimagro@yahoo.com.br
}

\section{RESUMO}

O artigo "Arte Educação: Necessidade ou superfluidade?" analisa determinados aspectos culturais da arte, a saber: acesso restrito a espaços de exposição, obras demasiadamente herméticas e elevado custo financeiro de produção, e, aponta alternativas para o desenvolvimento deste campo de conhecimento na educação formal. Não se quer com isso encerrar o debate acerca do assunto, e sim fomentá-lo para a real necessidade da arte educação no Brasil.

\section{ABSTRACT}

The article "Education Art: necessity or superfuousity?" intends to analyze art's cultural specifics aspects like: restrict access to art exhibition's areas, pices too complex to absorb and high financial costs to produce it, also shows ways to develop this kind of knowledge at the formal education. Its mainfull purpose it is not to exhaust this subject but to motivate the real necessity of educational art in Brazil. 
Arte Educação: Necessidade ou superfluidade?

"(...) a escola não deve converter-se em uma incubadora de pequenos monstros avidamente instruídos (...) a cultura é um privilégio. A escola é um privilégio. E não queremos que seja assim. Todos os jovens deveriam ser iguais perante a cultura..."

Gramsci

A arte muitas vezes é considerada como supérflua. Essa concepção é fundamentada no entendimento de que o Brasil tem outras necessidades primárias, como a alimentação e saúde, considerando suas profundas desigualdades sociais. Sendo assim o reino das necessidades básicas está em primazia quando comparado com o reino das artes ou da liberdade.

Poderíamos levantar, ainda, uma perspectiva excludente da arte, visto que, sua produção e consumo demandam grandes recursos financeiros, além de acesso restrito e espaços de exposições sofisticados e repletos de "regras de conduta" que inibem a visitação de um público mais amplo. E, ainda, as obras são demasiadamente herméticas impedindo a plena fruição pelas classes menos preparadas para isso.

Neste enfoque, ganha impulso a idéia de que a arte é majoritariamente entendida como elitista. Afirmar que a arte a princípio é elitista, é transformar em natural e eterno algo que é historicamente determinado, portanto sujeito a mudança. Num contexto histórico, uma parcela da produção plástica é apropriada econômica e ideologicamente pela classe dominante deste período, mas isso não determina arte como elitista.

Por outro lado, a arte erudita tem suas raízes fincadas nas classes subalternas, como Picasso, Gauguin e van Gogh. Outra consideração que devemos fazer é a de que o investimento financeiro que se faz em arte, se todo ele fosse revertido as questões sociais, os mesmos não passariam de assistencialismos sem possibilidades de mudança nos projetos políticos estratégicos estruturais que "mantêm" a exclusão, e então nos perguntamos: Além das classes excluídas serem privadas de seus direitos primários eles ainda tem que privar-se da estética?

Desse modo:

[...] ao invés de lançarmos indiscriminadamente nossas pedras sobre os produtos artísticos dos quais as classes opressoras econômica, política e culturalmente se assenhoraram, não seria mais revolucionário culturalmente fazer incidir um dos focos de luta contra valores estéticos que a classe dominante defende como eternos e imutáveis e através dos quais sua impostação de superioridade se perpetua? Caso contrario estaremos caindo no engodo mesmo do que pretendemos combater, dando posse ideológica e política ao que não passa de posse econômica, lendo os produtos artísticos através das lentes redutoras pelas quais as classes dominantes querem que eles sejam lidos" (SANTAELLA, 1995, p. 18)

Em síntese, alegar que a arte é supérflua fundamentando no entendimento 
que ela é elitista contribui para que a arte continue sendo instrumentalizada pelas elites dominantes. Isso, conforme Santaella (1995, p. 51), "não apenas não é justo, como também, [...] não é estratégico como forma de luta. Não se quer com isso afirmar que a arte pode, por si só mudar o curso da história, mas pode isso sim, constituir-se num elemento ativo desta mudança" (SANTAELLA, 1990, p. 51)

Segundo Robert Saunders a arte educação potencialmente atua numa perspectiva de mudanças sociais através do:

Desenvolvimento da percepção visual, da imaginação criativa, do desenvolvimento da flexibilidade na resolução criativa de problemas de todo tipo e da formação de valores estéticos que refletem tanto no entorno humano e urbano quanto nas obras de arte. Essa abordagem filosófica do ensino de arte reflete-se na escolha dos assuntos, materiais $e$ modos da linguagem artística (pintura, e cultura, desenho e gravura, muralismo, fotografia, etc.) que se tornam meios para o desenvolvimento de uma consciência social por meio da produção artística" (SAUNDERS, apud TEIXEIRA, 1999, p. 56)

A arte ou as linguagens artísticas são, muitas vezes, reduzidas à técnica de ilustração e ou veiculação dos conteúdos diversos para torná-los mais agradáveis e interessantes. Não que seja um erro buscar alternativas mais eficientes para as outras áreas de conhecimento, o erro é tornar a arte um mero instrumento disso.

Outro equívoco é pensar um aspecto da arte como agitação política, as artes tornam-se instrumento de persuasão e convencimento a serviço da política, seus aspectos cognitivos, técnicos e formais, característicos e específicos da produção artística tendem a ser menosprezados em detrimento do conteúdo das mensagens a serem veiculadas. "Todo o processo de conhecimento e de aprendizagem humanos se dá sob dois fatores: as vivências e as simbolizações". (DUARTE JR, 1998, p. 24) Ousaríamos dizer que todo 0 conhecimento científico parte ou partiu de uma experiência pessoal ou até mesmo subjetiva e sensível, especialmente após o advento do século das luzes "o iluminismo" . Toda a defesa da razão pura fez da emoção e da estética (aestesis = sentir o mundo) marginalizada, senão excluída do tripé: razão, emoção e vontade. E assim, essa concepção vem sendo perpetuada na escola, transmitindo conceitos desvinculados da vida e realidade concreta daqueles a quem se propôs a atender.

A linguagem é um consenso feito em consenso, tudo o que foge dessa lógica torna dificultosa sua compreensão, assim: "Se os símbolos lingüísticos são incapazes de nos apresentar integralmente os sentimentos, a arte surge como uma tentativa de fazê-lo". (DUARTE JR., 1998, p. 43)

E a atitude criadora, pode se afirmar que constitui um ato subversivo, porque propõe rebelar-se contra a "linguagem formal" e a "estética ideal", por isso Rubem Alves diz:

A rebeldia é a pressuposição básica de qualquer ato criativo. Ao ordenar e plantar um jardim, 
nos rebelamos contra a aridez da natureza. Ao lutar contra a enfermidade, nos rebelamos contra o sofrimento. Dizemos uma palavra de alento, porque nos rebelamos contra a solidão. Aceitamos a perseguição por causa de uma razão justa porque nos rebelamos contra a opressão e a injustiça. Os animais não podem rebelar-se. Precisamente por isso, tampouco podem ser criadores. Somente o que diz o seu não às coisas como são, mostra o desejo de sofrer pela criação do novo. O mundo da cultura seria, literalmente impensável, se não fosse pelos atos de rebeldia de todos aqueles que fizeram algo para construí-la. (1976, p. 149-150)

A arte, bem como toda a história é parte de uma dada conjuntura política, econômica, social e cultural, aí ela se situa e se desenvolve. Duarte Junior explica:

Por isso, na arte-educação, o que importa não é o produto final obtido; não é a produção de boas obras de arte. Antes, a atenção deve recair sobre o processo de criação. O processo pelo qual o educando deve elaborar seus próprios sentidos em relação ao mundo à sua volta. A finalidade da arteeducação deve ser, sempre, o desenvolvimento de uma consciência estética. (1998, p, 73)

O que existe de fato é uma correlação de forças entre a seriedade do trabalho de excepcionais e raros arteeducadores, e a hegemonia veiculada nos meios de comunicação de massa, em especial a TV, reforçando valores estéticos absolutos, decorativos e descartáveis.

\section{Bibliografia}

Alves, Rubem. Hijos Del mañana: imaginación, creatividad y renacimiento cultural Salamanca, Siguime, 1976

Duarte Jr, João Francisco. Porque Arteeducação?. $9^{\circ}$ ed. Papirus, São Paulo, 1998.

Santaella, Lucia. Arte e Cultura: Equívocos do elitismo. $3^{\circ}$ ed. Cortez, São Paulo, 1995.

Saunders, Robert J. ( in) Teixeira Coelho (org), Dicionário crítico de política cultura. (p.56 Arte-educação (1)), 1999. 